\title{
STRATEGI MISI SADRACH SUATU KAJIAN YANG BERSIFAT SOSIO HISTORIS
}

\author{
Silas Sariman \\ Sekolah Tinggi Theologia Abdiel \\ silassariman@gmail.com
}

\begin{abstract}
This writing is to explore the strategy of Christian mission of Kyai Sadrach. Sadrach was a Javanese who proclaimed the Gospel by the cultural approaches. Sadrach could spread the Gospel effectively and his cultural approaches were accepted by the Javanese people at the time. The writer mentions that Sadrach's mission was the Christian mission that reveals God's glory. To achieve the aim in explaining the strategy of Sadrach's mission, the writer talks about the life of Sadrach and his spiritual journey. The Church needs to learn from the strategy of Sadrah's mission in order for her to proclaim the Gospel contextually.
\end{abstract}

Keywords: Mission strategy, Kyai Sadrach, context, God's glory, Java

\section{Pendahuluan}

Istilah strategi berasal dari kata Yunani strategos atau jenderal ${ }^{1}$. Strategos juga dapat diterjemahkan sebagai komandan militer pada zaman demokrasi Athena. Dalam pengertian umum strategi adalah skenario untuk mencapai sasaran yang akan dituju. Suatu rencana yang cermat dari suatu kegiatan untuk mencapai sasaran khusus. Strategi juga rencana jangka panjang yang diikuti dengan tindakan-tindakan yang diarahkan untuk mencapai tujuan tertentu, yang pada umumnya adalah "kemenangan" atau "keberhasilan".

Istilah misi berasal dari kata Latin missio yang berarti pengutusan ${ }^{2}$. Dalam bahasa Inggris, Jerman, dan Prancis diterjemahkan mission. Dalam bahasa Belanda dipakai dua istilah untuk menterjemahkan missio, yang pertama adalah missie yang dipergunakan dikalangan Gereja Roma Katolik, sedangkan yang kedua adalah zending yaitu missio dari Gereja atau badan pekabaran Injil Protestan. Pemakaian istilah yang berbeda dari satu hal yang sama tersebut berasal dari zaman polarisasi dahulu, ketika orang memisahkan secara tajam dan sangat membedakan antara Gereja Roma Katolik dan Gereja Protestan ${ }^{3}$.

\footnotetext{
${ }^{1}$ Wilbert R Shenk, Mission Strategies (Grand Rapids: Michigan, 1993), 218.

${ }^{2}$ Arie de Kuiper. Missiologia (Jakarta: BPK Gunung Mulia, 2004), 9.

${ }^{3}$ Emanuel Gerrit Singgih. Berteologi Dalam Konteks: Pemikiran-pemikiran mengenai Kontekstualisasi Teologi di Indonesia (Yogyakarta: Yayasan Kanisius, 2000), 161.
} 
Jadi strategi misi adalah suatu skenario yang dirancang dengan tujuan untuk melaksanakan misi Allah secara holistik berdasarkan kebenaran Alkitab dengan memperhatikan konteks dan zamannya. Strategi misi merupakan salah satu usaha agar dapat melaksanakan misi Allah dengan tepat pada waktu yang tepat pula. Strategi misi tidak bersifat permanen atau paten, strategi misi bisa berbeda atau berubah sesuai dengan situasi, kondisi dan zamannya. Strategi misi yang berhasil pada suatu tempat dan situasi tertentu, belum tentu berhasil untuk tempat dan situasi yang berbeda.

Sekalipun istilah strategi misi tidak ada di dalam Alkitab, tetapi prinsip-prinsip strategi misi terdapat di dalam Alkitab. Dengan demikian dapat dikatakan bahwa strategi misi tidak bertentangan dengan kebenaran Firman Allah, bahkan dalam Perjanjian Lama maupun Perjanjian Baru didapati prinsip-prinsip strategi misi, yang dapat dijadikan pedoman bagi gereja dalam melaksanakan misi-Nya di dunia ini. Paper ini membahas strategi misi Kyai Sadrach. Tujuannya adalah Gereja masa kini dapat belajar tentang sebuah misi kontekstual itu di lakukan dan bagaimana Gereja terus belajar untuk melaksanakan amanat Agung Tuhan Yesus. Sebelum membahas lebih jauh mengenai strategi misi Kyai Sadrach maka perlu mengetahui latar belakang dari Kyai Sadrach dan kehidupannya.

\section{Masa Kecil Sadrach}

Mengenai tanggal dan tempat kelahiran Sadrach tidak diketahui secara jelas. Namun dari beberapa data yang ada dapat disimpulkan bahwa dia lahir pada tahun $1835^{4}$. Tempat kelahirannya di Kawedanan Jepara, di bagian utara Jawa Tengah, bahkan ada yang menyebutkan kelahirannya di desa Dukuh Sekti daerah Demak wilayah Jepara ${ }^{5}$. Ada juga yang menyebutkan kelahirannya di desa Luring dekat Semarang ${ }^{6}$. Tetapi yang penting semua tempat tersebut terletak di daerah pantai utara Jawa Tengah, tempat pertama kali Islam berpijak. Di mana banyak muslim santri dan haji yang tinggal di daerah tersebut.

Sadrach berasal dari dari keluarga petani miskin, yang pada waktu lahir diberi nama Radin. Sejak masa kecil Radin sudah berkelana dan menjadi pengemis. Kemungkinan Radin menjadi pengemis pada waktu masih pelajar, karena sudah menjadi tradisi murid-murid sekolah Alquran dan pesantren untuk mengemis sebagai bagian dari

\footnotetext{
${ }^{4}$ C Guillot, Kiai Sadrach: Riwayat Kristenisasi di Jawa (Jakarta: PT. Grafiti Pers, 1985), 55.

${ }^{5}$ I Sumanto, Kyai Sadrach: Seorang Pencari Kebenaran (Jakarta: BPK Gunung Mulia, 1974), 11.

${ }^{6}$ Soetarman Soedirman Partonadi, Komunitas Sadrach dan Akar Kontekstualnya: Suatu Kekristenan Jawa pada Abad XIX (Jakarta: BPK Gunung Mulia, 2001), 60.
} 
kurikulum. Hal itu biasanya dilakukan pada hari Kamis, yang dalam kata Jawa ngemis (mengemis), yang berasal dari hari Kemis (hari Kamis). Mengemis disini merupakan cara pengumpulan dana untuk kegiatan keagamaan dan pekerjaan sosial, dan hal ini dianggap sebagai pemberian derma, bagian dari kewajiban Islam $^{7}$.

Kemudian Radin diadopsi oleh keluarga Muslim yang cukup kaya, dan yang membesarkannya menurut tradisi Islam Jawa. Praktek adopsi oleh keluarga dari kelas yang lebih tinggi merupakan hal yang biasa pada waktu itu. Orang Jawa sering menyebutnya nyuwito (mengabdi untuk mendapat perlindungan), atau ngenger (mengabdi dengan menjalankan tugas-tugas), atau istilah magang (bekerja kepada seseorang dengan tujuan belajar). Ketiga pengabdian tersebut pada hakikatnya merupakan bentuk belajar dalam praktek. Hal ini dilakukan bukan karena alasan ekonomi, tetapi merupakan bagian dari sistem pendidikan tradisional Jawa.

\section{Masa Sadrach Mencari Ilmu}

Radin memulai belajar membaca Alquran di sekolah Alquran yang juga berfungsi sebagai sekolah umum. Tujuan utama sekolah Alquran adalah mempersiapkan anak-anak agar dapat memenuhi persyaratan minimum menjadi orang Jawa. Untuk mencapai tujuan tersebut, murid diperkenalkan dengan pelajaran dasar agama Islam dan kewajiban orang Jawa. Setelah lulus dari sekolah Alquran, Radin menjadi seorang pemuda Jawa seutuhnya. Radin tidak langsung melanjutkan ke pesantren, tetapi lebih dulu belajar sebagai murid di bawah bimbingan guru ngelmu Jawa, yang bernama Pak Kurmen atau Sis Kanoman di Semarang.

Kemudian pada waktu Radin berusia 17 tahun, ia pergi ke kota Jombang, Jawa Timur untuk belajar di pondok pesantren dalam rangka mencari ilmu sejati, terutama ilmu agama $^{8}$. Di antara murid di pondok pesantren itu, Sadrach termasuk murid yang cerdas dan rajin. Unsur terpenting dalam pesantren bukan pembentukan intelektual melainkan pembentukan spiritual. Di sini, murid dibekali dan dipersiapkan untuk terjun ke masyarakat dalam kehidupan sesungguhnya. Pesantren juga merupakan tempat pengembangan kebersamaan, yang merupakan aspek penting dalam hidup bermasyarakat.

Pada waktu Radin masih sebagai santri di Jombang, Jawa Timur, pada saat liburan dia pergi ke Mojowarno untuk bertemu dan mendengarkan pengajaran Jellesma, seorang

\footnotetext{
${ }^{7}$ Soetarman Soedirman Partonadi, Komunitas Sadrach dan Akar Kontekstualnya: Suatu Kekristenan Jawa pada Abad XIX (Jakarta: BPK Gunung Mulia, 2001), 61.

${ }^{8}$ I Sumanto, Kyai Sadrach: Seorang Pencari Kebenaran (Jakarta: BPK Gunung Mulia, 1974), 11.
} 
misionari Belanda yang tinggal di Mojowarno. Ini merupakan kontak pertama kali seorang santri Radin dengan ajaran Kristen dan dengan orang Belanda. Benih ajaran Kristen mulai tertanam dalam hatinya, ia merasa heran ketika mendengar tentang Injil keselamatan dan sangat tertarik untuk mempelajarinya.

Di sini Radin bersedia belajar sebagai murid tentang kekristenan kepada Jellesma. Namun pertemuan tersebut belum membuat Radin menjadi Kristen, karena Radin kemudian melanjutkan perjalanannya ke sebuah pondok pesantren di Ponorogo9 . Di pesantren tersebut di samping Radin belajar membaca dan menulis dengan aksara Arab, juga belajar menulis pegon (bahasa Jawa yang ditulis dengan aksara Arab), serta belajar membaca dan menulis dengan aksara Jawa. Dengan demikian Radin telah membekali diri dengan berbagai ilmu, sehingga paling tidak jauh lebih tinggi dari kebanyakan orang Jawa lainnya.

Setelah lulus dari pondok pesantrendi Jawa Timur, Radin kembali ke Semarang dan tinggal di Kauman. Pada saat itulah ia menambahkan nama Arab yang telah disesuaikan dengan bahasa Jawa, yaitu Abas, sehingga namanya menjadi Radin Abas. Radin seorang yang berwatak keras dalam mencari ilmu dan kebenaran, maka ia terus berusaha mencari guru yang dapat mengajarkan ilmu dan kebenaran kepadanya.

Selanjutnya Radin belajar dan berguru kepada Hoezoo, seorang pekabar Injil di Semarang. Radin diterima sebagai murid katekisasi dan setiap Minggu mengikuti kebaktian yang dipimpin oleh Hoezoo. Kemudian ia diperkenalkan oleh Pak Kurmen atau Sis Kanoman, dengan Kyai Ibrahim Tunggul Wulung, seorang pekabar Injil Jawa dari desa Bondo Jepara. Setelah mendengar banyak cerita tentang Kyai tersebut, Radin sangat tertarik dan ingin belajar menjadi murid Kyai Tunggul Wulung. Pertemuan tersebut membuat Radin makin terdorong dan condong kepada agama Kristen, sehingga akhirnya Radin menyatakan ingin menjadi orang Kristen. Kemudian bersama dengan Kyai Tunggul Wulung, Radin diajak ke Batavia untuk bertemu dengan Anthing.

Di Batavia Radin menjadi murid dan anak mas Anthing, ia ikut pendidikan Kristen yang dirikan oleh Anthing, untuk anak-anak muda pribumi. Setahun setelah lulus dari pendidikan tersebut, ia memutuskan untuk menjadi Kristen dan dibaptiskan dengan nama Sadrach. Dalam perjalanan dan pengalaman kehidupan Sadrach, paling tidak ia bisa

\footnotetext{
${ }^{9}$ C Guillot, Kiai Sadrach: Riwayat Kristenisasi di Jawa (Jakarta: PT. Grafiti Pers, 1985), 58.
} 
menguasai empat bahasa. Karena ia bukan saja bisa berbahasa Jawa, dan bahasa Indonesia (Melayu), melainkan juga bisa berbahasa Arab dan bahasa Belanda ${ }^{10}$.

Pengalaman pengembaraan Sadrach di Jawa Timur, Jawa Tengah, dan Jawa Barat mempunyai maksud dan tujuan tertentu, di samping dapat melihat saudara-saudara Kristen yang tersebar di mana-mana. Ia juga dapat membandingkan praktik pekabaran Injil dari masing-masing daerah tersebut sebagai pendirian kekristenannya, serta pengalaman melalui pergaulannya dengan para pendeta Belanda atau para pekabar-pekabar Injil Jawa.

Jadi dalam rangka mencari ilmu dan kebenaran, Sadrach telah mendapat berbagai ilmu dari bermacam guru yang berlainan antara lain:

a) Sadrach telah mendapatkan ilmu agama Islam, melalui sekolah Alquran ketika berada di Jawa Tengah dan beberapa sekolah pesantren yang berada di Jawa Timur (Jombang dan Ponorogo).

b) Sadrach telah mendapatkan ilmu Jawa, melalui Pak Kurmen atau Sis Kanoman sebagai guru ngelmu Jawa (sebelum menjadi Kristen), dan beberapa guru lain yang mengajar pada waktu di sekolah Alquran maupun pesantren.

c) Sadrach telah mendapatkan ilmu agama Kristen, melalui guru-guru agama Kristen di antaranya Jellesma dari Jawa Timur, Hoezoo dan Tunggul Wulung dari Jawa Tengah, dan Anthing dari Batavia (Jakarta).

d) Sadrach telah menguasai empat bahasa, yaitu bahasa Jawa, bahasa Indonesia (Melayu), bahasa Arab, dan bahasa Belanda. Hal ini yang lebih memudahkannya untuk berkomunikasi dengan berbagai pihak, terutama dalam rangka tugas pewartaan Injil.

\section{Masa Pertobatan dan Kerjasama dalam Pelayanan}

Ketika berada di Batavia, di rumah Anthing, mula-mula Radin diterima sebagai pembantunya (pelayan). Namun setelah dipandang baik dan rajin mengatur rumah tangga dan setia serta cerdas, akhirnya Radin diangkat menjadi anak mas Anthing. Selama tinggal bersama Anthing inilah, Radin mengambil keputusan untuk dibaptis. Ia mengikuti pelajaran katekisasi selama satu tahun, setelah lulus kemudian dibaptis di Gereja Zion (sekarang GPIB Zion) dengan nama baptisan Sadrach. Sejak itu namanya menjadi Radin Sadrach, dan akhirnya lebih dikenal dengan nama Sadrach ${ }^{11}$.

\footnotetext{
${ }^{10}$ Majalah Rohani Populer Bahana. Jejak Langkah Kiai Sadrach: Kristenisasi di Jawa. (Yogyakarta: Andi Offset. No.05/TH.III/VOL, 17. Oktober, 1992), 11.

${ }^{11}$ I Sumanto, Kyai Sadrach: Seorang Pencari Kebenaran. (Jakarta: BPK Gunung Mulia, 1974), 15.
} 
Pelayanan awal yang dilakukan Sadrach adalah bekerjasama dengan Anthing dan King untuk menjual buku-buku Kristen, sambil menyebarkan brosur dan buku-buku tentang agama Kristen dari rumah ke rumah di seputar Batavia. Namun karena pelayanan ini dianggap tidak cocok, maka Sadrach minta izin kepada Anthing untuk kembali ke Jawa Tengah guna melanjutkan tugasnya dalam pemberitaan Injil kepada orang Jawa ${ }^{12}$. Di Jawa Tengah Sadrach bergabung dan bekerjasama dengan Tunggul Wulung dan Pak Kurmen, untuk membangun (babat hutan) desa-desa Kristen di Bondo Jepara.

Setelah bekerjasama dengan Tunggul Wulung selama hampir setahun di Bondo, lalu Sadrach memutuskan untuk meninggalkan desa Bondo. Dikatakan bahwa Sadrach meninggalkan desa Bondo dengan air mata berlinang ke suatu tempat yang akan ditunjukkan Tuhan ${ }^{13}$. Apapun alasan di balik kepergian Sadrach dari desa Bondo ke Purworejo, yang jelas Sadrach telah memulai fase yang baru dalam pelayanan.

Di Purworejo Sadrach kemudian bekerjasama dengan Stevens-Philips (keluarga Philips). Sadrach diterima oleh Stevens-Philips untuk bekerja bersama dengan dua pembantu lainnya yaitu Abisai Reksodiwongso dan Tarub. Akibat dari kerjasama dengan para pembantunya, gereja yang berada di rumah Stevens-Philips mengalami pertumbuhan pesat. Khususnya Sadrach yang memiliki bakat besar dalam penginjilan, sehingga dalam waktu singkat Sadrach menjadi penginjil Jawa yang menonjol, sebagai pembela kekristenan Jawa yang berani seperti Tunggul Wulung, gurunya ${ }^{14}$. Hasil penginjilan tersebut diserahkan kepada Stevens-Philips untuk diajar katekisasi. Jadi nampak jelas di sini kerjasama antara Sadrach yang bertugas utuk menginjil dan membawa jiwa kepada Kristus, sedangkan Stevens-Philips bertugas untuk mengkatekisasi dan menjadikan mereka murid Kristus.

Setelah beberapa lamanya bekerjasama dengan Stevens-Philips, kemudian Sadrach pergi ke Karangjoso. Keputusan Sadrach untuk meninggalkan Stevens-Philips bermotifkan kepercayaan diri dan semangat untuk mandiri dan merdeka, dua sifat umum yang dimiliki oleh kyai Jawa. Karangjoso adalah desa pertama tempat Sadrach dengan bebas mendirikan sebuah jemaat Kristen Jawa setempat. Dalam perkembangan selanjutnya, Karangjoso menjadi pusat jemaat Sadrach. Sadrach tinggal di Karangjoso dan menikah dengan Roro Tompo alias Debora yang dikenal sebagai penginjil perempuan pribumi. Namun karena

\footnotetext{
${ }^{12}$ Ibid., 16.

${ }^{13}$ Soetarman Soedirman Partonadi, Komunitas Sadrach dan Akar Kontekstualnya: Suatu Kekristenan Jawa pada Abad XIX (Jakarta: BPK Gunung Mulia, 2001), 68.

${ }^{14}$ Ibid., 71.
} 
dalam pernikahan itu tidak mempunyai anak, maka Sadrach mengadopsi anak laki-laki dari Markus, yang bernama Yotham ${ }^{15}$.

Jemaat Karangjoso dengan cepat terus berkembang sehingga tidak sampai setahun, maka akhirnya pada tahun 1871 di Karangjoso dibangun sebuah gereja yang menyerupai (disebut) masjid ${ }^{16}$. Gereja tersebut dengan arsitektur berbentuk Joglo (rumah khas Jawa), dengan Kyai Sadrach sebagai gembalanya (sekarang dikenal GKJ Karangjoso).

Selanjutnya Sadrach bekerjasama dengan Wilhelm, meskipun keduanya memiliki latar belakang yang berbeda namun mereka memiliki semangat yang sama dan meletakkan dasar yang kokoh bagi masa depan jemaat. Sadrach datang ke Purworejo untuk meminta Wilhelm menjadi pendeta jemaat, Wilhelm menanggapi dengan positif dan menerima tawaran tersebut. Lalu jemaat memilih secara resmi nama Golongane Wong Kristen Mardiko (kelompok orang Kristen yang merdeka) dan mengakui Wilhelm sebagai pendeta mereka.

Wilhelm sebagai seorang pekabar Injil yang masih muda, idealis, dan optimis yang bekerja sama dengan Sadrach menetapkan pemahamannya sendiri mengenai prinsip pekabaran Injil. Di mana ia menganggap Sadrach sebagai rekan kerja dalam segala hal. Mereka tidak bekerja selaku pengawas dan dan pembantu, tetapi dalam kedudukan yang sederajat. Ini adalah sikap revulosioner yang belum pernah dipraktekkan sebelumnya. Selama menjalin kerjasama yang makin membawa berkat di tengah jemaat tersebut, Sadrach terus melakukan penginjilan untuk memperluas jemaat. Sedangkan Wilhelm mengkonsentrasikan diri pada konsolidasi internal, mengorganisasi kembali, mengajar, berkhotbah, menggembalakan jemaat, dan pelayanan sakramen. Selain itu Wilhelm juga menerjemahkan beberapa buku dari bahasa Belanda ke dalam bahasa Jawa. Semua hasil terjemahan tersebut dimaksudkan sebagai buku pegangan gereja untuk mendidik jemaat dalam standar gereja sejati. Di sini nampak adanya perpaduan yang saling melengkapi dari kedua pemimpin yang berdampak sangat menjanjikan bagi perkembangan jemaat.

\section{Strategi Misi Sadrach}

Misi Penginjilan Sadrach memiliki beberapa metode yang diterapkan dalam misinya antara lain.

\footnotetext{
${ }^{15}$ I Sumanto, Kyai Sadrach: Seorang Pencari Kebenaran (Jakarta: BPK Gunung Mulia, 1974), 30.
}

${ }^{16}$ C Guillot, Kiai Sadrach: Riwayat Kristenisasi di Jawa (Jakarta: PT. Grafiti Pers, 1985), 82. 
a) Penginjilan Pribadi

Sadrach memulai misinya dengan melakukan penginjilan pribadi dari rumah ke rumah di sekitar Batavia. Penginjilan ini dilakukan dengan membagi-bagikan brosur dan buku-buku rohani kepada setiap orang yang dijumpainya ${ }^{17}$. Juga melakukan penginjilan pribadi kepada beberapa orang tokoh Jawa, dengan datang ke rumah orang yang dituju, berbicara hingga malam hari kadang bermalam juga di situ, kemudian pindah ke tempat lan lagi. Suatu keistimawaan Sadrach, bahwa orang-orang yang dijumpainya, orang-orang itu akhirnya bertobat dan menjadi Kristen ${ }^{18}$. Di antaranya ketika Sadrach datang ke rumah Kyai Ibrahim, yang tinggal di desa Sruwoh wilayah Kutoarjo, melalui percakapan pribadi tentang kebenaran membawa Kyai Ibrahim percaya pada Kristus dan akhirnya di baptis di Purworejo.

b) Penginjilan Massal

Pada masa itu memberitakan Injil secara massal di tempat terbuka tidak ada persoalan. Waktu itu Sadrach datang ke desa Cangkrep wilayah Bagelen, dengan izin kepala desa setempat, ia mengundang penduduk desa tersebut. Mereka yang datang dari berbagai aliran kepercayaan, yaitu agama Islam, Budha, orang-orang ahli sihir dan nujum. Sadrach memberitakan Injil keselamatan dengan berani, dengan cara dan gayanya sendiri, ternyata banyak orang-orang yang bertobat dan menerima Tuhan Yesus sebagai Juruselamat mereka ${ }^{19}$.

c) Penginjilan melalui Debat Ngelmu

Sebenarnya cara Sadrach menyebarkan agama Kristen selalu dimulai dengan mengunjungi guru-guru ngelmu terkemuka di daerah-daerah sambil menyakinkan mereka terhadap kepercayaan Kristen. Dengan cara berdiskusi ("parembagan ilmu”) mengenai kebenaran dan keselamatan di dalam Kristus. Jika tidak berhasil, maka baru ia menantang mereka untuk mengadakan debat ngelmu di depan umum, untuk mengetahui siapa di antara mereka yang lebih tinggi ngelmunya ${ }^{20}$. Metode seperti itu sudah ada sebelum Sadrach, metode tersebut pernah digunakan Tunggul Wulung (guru Sadrach), ketika berhadapan dengan Pak Kurmen (Sis Kanoman, guru ngelmu Jawa), yang akhirnya bertobat menjadi

\footnotetext{
${ }^{17}$ Soetarman Soedirman Partonadi, Komunitas Sadrach dan Akar Kontekstualnya: Suatu Kekristenan Jawa pada Abad XIX (Jakarta: BPK Gunung Mulia, 2001), 67.

${ }^{18}$ I Sumanto, Kyai Sadrach: Seorang Pencari Kebenaran (Jakarta: BPK Gunung Mulia, 1974), 23.

19 Ibid., 24.

${ }^{20}$ C Guillot, Kiai Sadrach: Riwayat Kristenisasi di Jawa (Jakarta: PT. Grafiti Pers, 1985), 79. 
Kristen. Jadi salah satu metode yang dipakai Sadrach dalam memberitakan Injil adalah dengan debat ngelmu dengan guru-guru ngelmu lainnya ${ }^{21}$.

d) Penginjilan kepada Orang-orang Kunci

Dalam pewartaan Injil Sadrach juga memiliki sasaran kepada orang kunci (pemimpin, penguasa, tokoh, orang yang punya pengaruh). Seperti para kyai (Kyai Ibrahim, Kyai Kasanmentaram, Kyai Karyodikromo, dll), para guru ahli nujum (R. Ranukusumo dan Setrodiwongso), dan para guru ngelmu Jawa lainnya. Metode ini memang sangat strategis karena dengan memenangkan seorang pemimpin yang punya pengaruh kepada banyak orang, dan menjadi Kristen, dapat membawa dampak yang besar bagi orang-orang yang ada di bawahnya. Ternyata dengan metode ini Sadrach dapat membawa banyak orang menjadi pengikutnya, untuk dibawa menjadi pengikut Kristus.

e) Penginjilan Kontekstual

Sadrach dalam memberitakan Injil memakai konteks setempat (Jawa), di mana ia dikenal sdebagai penginjil dengan cara khas Jawa. Hal ini nampak mulai dari bahasa yang dipakai adalah bahasa Jawa, ia juga tetap mempertahankan tradisi-tradisi Jawa dengan seleksi seperlunya ${ }^{22}$. Membangun gedung Gereja dengan khas Jawa "Joglo" yang sering disebut "masjid". Bangunan tersebut didirikan dengan model masjid Jawa, yang menginterprestasikan simbol-simbol yang ada secara unik berdasarkan pengertian Kristen. Atap yang bersusun tiga merupakan simbol Trinitas. Cakra yang menggantikan bulan sabit Islam, diambil dari cerita wayang dan diinterpretasikan ulang sebagai lambang kuasa Injil Allah yang mampu menembus kekerasan hati manusia ${ }^{23}$. Dengan kata lain Sadrach ingin membumikan Injil atau menjawakan Injil, yang sekarang disebut kontekstualisasi.

f) Penginjilan dengan Mendirikan desa Kristen

Sama seperti Coolen tahun 1829 membuka hutan dan membangun desa Ngoro Jawa Timur menjadi desa Kristen. Abisai Ditotruno tahun 1846 yang membuka hutan dan membangun desa Mojowarno desa Kristen, dan Tunggul Wulung tahun 1868 membangun desa Bondo Jepara Jawa Tengah menjadi desa Kristen. Demikian juga Sadrach tahun 1870 membangun desa Karangjoso menjadi desa Kristen ${ }^{24}$. Desa Kristen diperlukan sebagai tempat bagi orang-orang Kristen baru, terutama bagi mereka yang mengalami penolakan (diusir) dari keluarga karena menjadi Kristen. Sebagai contoh ketika Kyai Karyodikromo

\footnotetext{
${ }^{21}$ Emanuel Gerrit Singgih, Berteologi Dalam Konteks: Pemikiran-pemikiran mengenai Kontekstualisasi Teologi di Indonesia (Yogyakarta: Yayasan Kanisius, 2000), 97.

${ }^{22}$ C Guillot, Kiai Sadrach: Riwayat Kristenisasi di Jawa (Jakarta: PT. Grafiti Pers, 1985), 198.

${ }^{23}$ Soetarman Soedirman Partonadi, Komunitas Sadrach dan Akar Kontekstualnya: Suatu Kekristenan Jawa pada Abad XIX (Jakarta: BPK Gunung Mulia, 2001), 250.

${ }^{24}$ I Sumanto, Kyai Sadrach: Seorang Pencari Kebenaran (Jakarta: BPK Gunung Mulia, 1974), 30.
} 
dan adiknya, Kyai Wirodikromo menjadi Kristen, mereka mendapat tantangan keras dari orang tua dan mertuanya, sehingga mereka dengan keluarganya pindah ke Karangjoso. Disamping itu desa Kristen juga sebagai tempat untuk kelanjutan pemeliharaan iman bagi orang Kristen baru.

g) Penginjilan dengan Mengusir Roh-roh Jahat

Rupanya Sadrach menjadi guru yang berpengaruh dan terkenal, bukan hanya karena kemampuannya dalam berdebat umum, melainkan juga karena kemampuannya untuk mengusir dan mengendalikan roh-roh jahat. Di Karangjoso terdapat sawah-sawah yang angker, sehingga yang berani mengerjakannya tiba-tiba mati mendadak. Banyak orang tidak berani mengerjakan sawah tersebut, tetapi Sadrach berani menyewa tanah tersebut dan menggarapnya tanpa ada musibah apa-apa. Karena Roh yang ada pada diri Sadrach lebih besar dari roh-roh yang lain. Sadrach juga mengusir roh-roh jahat yang ada pada keris-keris, dan melakukannya dengan nama Allah Tritunggal ${ }^{25}$.

h) Penginjilan melalui Penyembuhan

Sadrach mengumpulkan pengikutnya setiap Selasa Kliwon yang disebut selapan yaitu setiap 35 hari sekali, pada waktu itulah Sadrach mengajarkan dasar-dasar iman Kristen dan menyembuhkan orang sakit dengan doa sambil memberikan kepada mereka air suci (air putih), menyemburkan atau mengusap dengan air ludah disertai dengan pembakaran kemenyan dan menggunakan air yang di permukaannya mengapung daundaun bunga ${ }^{26}$. Itulah sebabnya Sadrach dianggap oleh pengikutnya sebagai Guru kuasa, digdaya, lan pinter, karena ia dapat menyembuhkan berbagai penyakit. Apa yang dilakukan Sadrach adalah merupakan praktek dan teknik guru ngelmu untuk menolong orang lain. Hal ini dilakukan sebagai sarana penginjilan melalui pengobatan tradisional.

Selain pelayanan penginjilan dengan berbagai cara tersebut, Sadrach juga melakukan pelayanan sosial. Sekalipun mungkin dapat dikatakan baru dalam taraf yang sederhana.

a) Pelayanan kepada Anak Terlantar

Demi perhatiannya kepada anak-anak yang miskin dan terlantar Sadrach menampung anak-anak tersebut di rumahnya ${ }^{27}$. Hal ini dilakukan sebagai wujud nyata kepeduliannya terhadap kesejahteraan mereka. Untuk kebutuhan tersebut dalam kumpulan selapan di Karangjoso, orang membawa dan mengumpulkan uang untuk menolong orang

\footnotetext{
${ }^{25}$ C Guillot, Kiai Sadrach: Riwayat Kristenisasi di Jawa (Jakarta: PT. Grafiti Pers, 1985), 198.

${ }^{26}$ Ibid., 197.

${ }^{27}$ I Sumanto, Kyai Sadrach: Seorang Pencari Kebenaran (Jakarta: BPK Gunung Mulia, 1974), 67.
} 
miskin termasuk untuk kebutuhan anak-anak terlantar tersebut. Juga melalui pengumpulan zakat satu sen perhari dari setiap rumah tangga anggota jemaat. Pengumpulan uang tersebut digunakan dalam rangka pelayanan diakonia dan upaya peningkatan sosial ekonomi jemaat ${ }^{28}$.

b) Membuka Lapangan Pekerjaan

Usaha yang Sadrach lakukan kemudian ialah dengan membeli sebidang tanah bekas tanah pabrik sekalipun dengan uang pinjaman (karena biaya yang cukup besar) dan membuka lapangan pekerjaan bagi anak-anak terlantar tersebut, di lahan yang telah dibeli $^{29}$. Mereka dapat bekerja dan bisa mendapatkan hasil dari pekerjaan tersebut. Jadi anak-anak terlantar tersebut sambil bekerja mereka juga berguru. Hal ini berarti bahwa secara tidak langsung Sadrach telah melakukan pelayanan untuk mengentaskan pengangguran dan kebodohan. Dengan kata lain Sadrach dalam misinya juga memperhatikan dunia pendidikan dan dunia lapangan kerja.

c) Mendirikan semacam Bank Kredit

Rupanya hasil pengumpulan uang dari anggota jemaat tersebut juga sebagian dipinjamkan kepada orang-orang yang membutuhkan untuk modal usaha mikro dengan bunga rendah. Mereka mendirikan seperti bank kredit (sejenis koperasi), hal ini dilakukan untuk melawan praktik lintah darat, yang biasanya meminjamkan uang dengan bunga yang tinggi. Dalam hal ini Sadrach memanfaatkan bentuk koperasi yang telah ada di antara masyarakat desa Jawa ${ }^{30}$.

Misi pemuridan, sekalipun Sadrach jiwa pelayanannya terpanggil dibidang penginjilan, namun bukan berarti bahwa ia sama sekali tidak melakukan pelayanan pemuridan. Ternyata Sadrach juga melakukan proses pemuridan sehingga banyak murid yang dihasilkannya.

a) Pemuridan bersama Orang Lain

Pada mulanya Sadrach bekerjasama dalam proses pemuridan dengan orang-orang yang dipercayai dan dipandang dapat melakukan pemuridan. Sadrach pernah bekerjasama dengan keluarga Philips. Caranya yaitu Sadrach pergi untuk menginjil dan hasil jiwa-jiwa yang telah diinjili diserahkan kepada keluarga Philips untuk dimuridkan. Termasuk orang-

\footnotetext{
${ }^{28}$ Soetarman Soedirman Partonadi, Komunitas Sadrach dan Akar Kontekstualnya: Suatu Kekristenan Jawa pada Abad XIX (Jakarta: BPK Gunung Mulia, 2001), 218.

${ }^{29}$ I Sumanto, Kyai Sadrach: Seorang Pencari Kebenaran (Jakarta: BPK Gunung Mulia, 1974), 67.

${ }^{30}$ Soetarman Soedirman Partonadi, Komunitas Sadrach dan Akar Kontekstualnya: Suatu Kekristenan Jawa pada Abad XIX (Jakarta: BPK Gunung Mulia, 2001), 246.
} 
orang Kristen baru yang dimenangkan melalui debat ngelmu dari daerah Bagelen, juga dibawa kepada Nyonya Philips untuk diajar katekisasi dan dimuridkan.

b) Pemuridan Sendiri

Setelah bekerjasama dengan orang lain dalam proses pemuridan selanjutnya Sadrach juga melakukan pemuridan sendiri. Di mana ia mulai mengajar dan melatih orangorang yang telah diinjili untuk kemudian dimuridkan. Dengan modal pengetahuan dan pengalamannya Sadrach mengajar murid-muridnya dengan cara khas Jawa. Sadrach mengajar murid-muridnya untuk mengenal Yesus sebagai Juruselamat, Sepuluh Hukum Allah, Doa Bapa Kami, juga Pengakuan Iman Rasuli ${ }^{31}$. Di sini nampak Sadrach sudah mulai mandiri, sekalipun hubungannya dengan keluarga Philips masih tetap berjalan baik. Di antara murid-murid Sadrach yang sangat aktif dalam memberitakan Injil, yaitu Paulus Kasanmentaram, Ibrahim, Yohanes, Markus dari desa Banjur, Musa dan Sulaiman.

Tersebarnya murid-murid Sadrach dan murid-murid yang dihasilkan oleh muridmurid Sadrach di berbagai daerah memunculkan kelompok-kelompok orang Kristen baru yang mengakui Sadrach sebagai guru dan kyai mereka, meskipun mereka belum pernah bertemu dengan Sadrach $^{32}$.

\section{Strategi Misi Keagungan Tuhan}

Strategi misi yang diterapkan Sadrach dalam pemberitaan Injil Yesus Kristus kepada orang-orang Jawa, sangat berbeda dengan apa yang dilakukan oleh para misionaris. Demikian juga pendekatan yang dipakai sangat berbeda. Hal ini bukan semata-mata karena Sadrach telah dilahirkan dan dibesarkan di Jawa, melainkan karena Sadrach seorang yang memegang teguh adat dan budaya Jawa, serta seorang pemberani yang berani tampil beda dalam pewartaan Injil. Itu berarti Sadrach siap untuk menghadapi segala risiko dari orangorang atau kelompok-kelompok tertentu yang tidak sepaham dengan dirinya.

Rupanya dalam melakukan misi Yesus Kristus dengan berbagai cara tersebut, sesungguhnya Sadrach menerapkan strategi misi keagungan Tuhan. Suatu strategi misi yang berbeda ("baru”), yang bertujuan untuk membawa orang-orang untuk mengenal akan kebesaran dan keagungan Tuhan di dalam diri Yesus Kristus. Strategi misi keagungan Tuhan yang diterapkan Sadrach tersebut bukan semata-mata untuk membawa orang menjadi Kristen dan masuk gereja, apa lagi untuk menjadikan mereka sebagai pengikutnya

\footnotetext{
${ }^{31}$ I Sumanto, Kyai Sadrach: Seorang Pencari Kebenaran (Jakarta: BPK Gunung Mulia, 1974), 27.

${ }^{32}$ Soetarman Soedirman Partonadi, Komunitas Sadrach dan Akar Kontekstualnya: Suatu Kekristenan Jawa pada Abad XIX (Jakarta: BPK Gunung Mulia, 2001), 100.
} 
(jemaatnya). Hal ini telah dibuktikan dengan kerelaan Sadrach untuk menyerahkan orangorang yang telah diinjili di daerah Purworejo kepada Nyonya Philips, juga menyerahkan hasil pekabaran Injil di daerah Kendal kepada Tn. Heller serta menyerahkan pengikutpengikutnya di daerah Pekalongan kepada Tn. Jungst.

Bagi Sadrach yang penting melalui strategi misi keagungan Tuhan supaya banyak orang memiliki pengenalan akan Allah yang benar dan Allah yang Mahabesar di dalam diri Yesus Kristus. Dalam hal ini Sadrach ingin dalam hidupnya dapat menjadi seperti mercusuar, yang dapat memberikan penerang, dan arah jalan bagi orang-orang yang dalam kegelapan. Lalu membawa mereka kepada sumber terang dan jalan kebenaran yang sejati di dalam Yesus Kristus. Pengenalan secara pribadi akan kebesaran dan keagungan Tuhan yang ditemukan di dalam Yesus Kristus, membuat Sadrach rindu untuk membagikan pengalaman tersebut kepada orang lain. Supaya banyak orang lain juga memiliki pengenalan secara pribadi terhadap Yesus Kristus, sebagai Allah yang Mahakasih, Mahakuasa, dan Mahabesar.

\section{Hasil Misi Sadrach}

Pada bagian akhir ini akan dibahas mengenai hasil misi Sadrach baik itu misi yang bersifat kualitas maupun kuantitas.

1) Hasil misi secara kualitas mulai dari awal kehidupan para petobat baru, sampai pertumbuhan kerohanian mereka serta munculnya murid-murid Kristus.

Kualitas rohani petobat baru, mula-mula mereka baru memiliki dasar iman yang masih dangkal. Selanjutnya mereka diajar untuk mengenal Yesus sebagai Juruselamat, tentang doa Bapa kami, Sepuluh Hukum Tuhan, dan 12 Pengakuan Iman Rasuli. Kemudian mereka mulai menggabungkan diri dengan komunitas Kristen yang lain, untuk bersekutu, berdoa, dan memuji Tuhan ${ }^{33}$. Kehidupan baru dalam Kristus tersebut nampak jelas dalam kerinduan mereka untuk berbakti dan bersekutu serta kerelaan mereka untuk menyumbangkan uang untuk membangun gedung gereja atau keperluan yang lainnya.

Pertumbuhan rohani petobat baru tercermin dalam kehidupan moralitas mereka. Sadrach memperhatikan hidup jemaatnya. Ia menekankan kepada jemaatnya untuk hidup dalam kesalehan dan kejujuran. Sadrach sendiri terkenal dengan perilakukanya yang jujur. Sadrach sangat menentang terhadap penyakit masyarakat (perjudian, poligami, candu), bahkan melarang pesta tradisional tayuban. Dampak dari sikap tersebut, maka pada

\footnotetext{
${ }^{33}$ Soetarman Soedirman Partonadi, Komunitas Sadrach dan Akar Kontekstualnya: Suatu Kekristenan Jawa pada Abad XIX (Jakarta: BPK Gunung Mulia, 2001), 178.
} 
umumnya para pengikutnya tidak terlibat dalam perjudian, poligami, maupun penggunaan candu. Jemaat pengikut Sadrach kehidupannya ditandai dengan kesederhanaan, kerendahan hati, dan kejujuran.

Sadrach menghasilkan murid dan terus membina kerohanian pengikutnya. Dari hasil pembinaan tersebut kemudian muncul murid-murid yang ikut membantu dan terlibat dalam pekabaran Injil. Mula-mula mereka menjadi murid Sadrach, dan selanjutnya mereka menjadi murid Kristus. Proses untuk menjadikan murid ini tidak mudah dan dibutuhkan proses waktu yang cukup serta pengorbanan yang besar.

2) Hasil misi secara kuantitas baik berupa terbentuknya suatu komunitas orang-orang Kristen di berbagai daerah, sampai pada jumlah bilangan orang-orang yang telah diselamatkan, maupun berdirinya gedung-gedung gereja di beberapa tempat.

Pelayanan penginjilan Sadrach menghasilkan petobat-petobat baru sehingga memunculkan terbentuknya komunitas baru yaitu komunitas orang-orang percaya pada Kristus. Komunitas Kristen tersebut berada di beberapa daerah. Mereka mengadakan pertemuan di rumah-rumah untuk berdoa, memuji Tuhan dan belajar Firman Tuhan ${ }^{34}$. Komunitas Kristen yang muncul dan hadir di tengah-tengah masyarakat di beberapa daerah tersebut menjadi daya tarik tersendiri bagi lingkungannya. Kelompok-kelompok orang Kristen tersebut terus mengalami perkembangan karena mereka dengan giat menyaksikan pengalaman iman mereka yang baru kepada orang lain. Komunitas-komunitas Kristen di beberapa daerah inilah yang kemudian menjadi cikal bakal berdirinya jemaat-jemaat baru.

Sejarah pelayanan penginjilan Sadrach menunjukkan adanya pertambahan jumlah bilangan orang-orang yang bertobat dan menerima Kristus sebagai Juruselamat. Pertambahan tersebut terus terjadi tahun demi tahun dan dalam areal yang semakin meluas di daerah-daerah yang baru. Dalam jangka waktu selama tiga tahun (1871-1873) telah dibaptis sebanyak 612 orang $^{35}$. Perkembangan selanjutnya, data statistik menunjukkan sepanjang tahun 1907 sampai 1929 rata-rata tiap tahun dibaptiskan sebanyak 315 orang. Pada akhirnya mencapai jumlah seluruhnya pada bulan Mei 1933 sebanyak 7.552 orang, yang tersebar di sembilan daerah Jawa Tengah (Yogyakarta, Surakarta, Kebumen, Pekalongan, Banyumas, Magelang, Wonosobo, Purworejo, dan Semarang ${ }^{36}$.

Berdirinya gedung-gedung Gereja yang letaknya tidak terlalu jauh dengan tempat tinggal jemaat. Dengan kesadaran dan kebutuhan tersebut maka mereka dengan sukarela

\footnotetext{
${ }^{34}$ Ibid., 50.

${ }^{35}$ C Guillot, Kiai Sadrach: Riwayat Kristenisasi di Jawa (Jakarta: PT. Grafiti Pers, 1985), 81.

${ }^{36}$ Soetarman Soedirman Partonadi, Komunitas Sadrach dan Akar Kontekstualnya: Suatu Kekristenan Jawa pada Abad XIX (Jakarta: BPK Gunung Mulia, 2001), 178), 117-118.
} 
dan sukacita memberikan persembahan berupa tenaga ataupun bahan-bahan kayu untuk membangun gereja atau pada waktu itu disebut masjid. Dalam perkembangan selanjutnya kemudian jumlah gereja menjadi 86 jemaat lokal yang tersebar di sembilan daerah Jawa Tengah. Yaitu di Yogyakarta ada 20 Jemaat, di Surakarta ada 14 Jemaat, di Kebumen ada 12 jemaat, di Pekalongan ada 12 jemaat, di Banyumas ada 9 jemaat, di Magelang ada 7 jemaat, di Wonosobo ada 6 Jemaat, di Purworejo ada 4 Jemaat, dan di Semarang ada 2 jemaat.

\section{Kesimpulan}

Setelah melakukan kajian mengenai kehidupan, pelayanan, dan strategi misi yang dilakukan Sadrach, maka dapat disimpulkan sebagai berikut.

Pertama, tulisan ini bukan dimaksudkan untuk mengungkap tentang keberhasilan atau kehebatan Sadrach, melainkan untuk mengenali semua seluk beluk misi yang telah dilakukannya dengan segala kelebihan dan kekurangannya, dengan kekuatan dan kelemahannya. Karena pasti ada segi positif maupun negatif dari misi yang telah Sadrach lakukan.

Kedua, pada zaman Sadrach hidup — abad XIX — telah berkembang berbagai macam strategi misi. Mulai dari strategi misi gereja resmi, yang diwakili oleh gereja Katolik dan gereja Protestan, dan strategi misi para misionaris.

Ketiga, pada waktu itu Sadrach hadir sebagai pekabar Injil pribumi yang terbeban untuk membawa dan memenangkan orang pribumi kepada Kristus (pribumi memenangkan pribumi). Sadrach muncul sebagai penginjil Jawa yang menyajikan Injil kepada orangorang Jawa dengan memakai budaya Jawa, sehingga hal ini bukan saja menjadi solusi atas pergumulan orang pribumi, melainkan juga lebih mengena dan mudah untuk diterima dan dipahami.

Keempat, Sadrach telah mengembangkan strategi misi yang unik dan yang berbeda dengan strategi misi yang lain, yaitu dengan strategi misi keagungan Tuhan. Yakni suatu misi untuk membawa orang-orang untuk mengenal kebesaran dan keagungan Tuhan. Sadrach ingin berbagi pengalaman Iman dengan orang lain, bahwa Allah yang disembah adalah Allah yang Mahabesar, Mahakasih, yang kuasa dan kemuliaan-Nya lebih besar dari yang lain. Bahwa Allah yang disembah di dalam diri Yesus Kristus, yang berkuasa atas bumi dan surga, itulah kebenaran yang sejati. Pengenalannya secara pribadi kepada Gusti kang Mohaagung (Allah yang Mahabesar) di dalam diri Yesus Kristus, yang mendorong 
Sadrach untuk hidup mengagungkan Tuhan dan rindu mengajak orang lain untuk hidup menyembah dan mengagungkan Tuhan.

Kelima, Sadrach adalah seorang penginjil pribumi abad XIX, yang menjadi cikal bakal berdirinya gereja-gereja Kristen Jawa di Indonesia, yang peninggalannya masih ada sampai sekarang. Sekalipun dalam melaksanakan misi-Nya menghadapi banyak tantangan dan hambatan, namun Sadrach tetap setia melakukan tugas panggilan yang Tuhan percayakan sampai pada akhir hidupnya. Perjuangan dan kesetiaan Sadrach tersebut membuahkan, hasil misi baik secara kualitas maupun secara kuantitas.

\section{Kepustakaan}

Guillot, C. Kiai Sadrach: Riwayat Kristenisasi di Jawa. Jakarta: PT. Grafiti Pers, 1985.

Majalah Rohani Populer Bahana. Jejak Langkah Kiai Sadrach: Kristenisasi di Jawa. Yogyakarta: Andi Offset. No.05/TH.III/VOL, 17. Oktober, 1992.

Kuiper, Arie de. Missiologia. Jakarta: BPK Gunung Mulia, 2004.

Partonadi, Soetarman Soedirman. Komunitas Sadrach dan Akar Kontekstualnya: Suatu Kekristenan Jawa pada Abad XIX. Jakarta: BPK Gunung Mulia, 2001.

Shenk, Wilbert R. Mission Strategies. Grand Rapids: Michigan, 1993.

Singgih, Emanuel Gerrit. Berteologi Dalam Konteks: Pemikiran-pemikiran mengenai Kontekstualisasi Teologi di Indonesia. Yogyakarta: Yayasan Kanisius, 2000.

Sumanto, I. Kyai Sadrach: Seorang Pencari Kebenaran. Jakarta: BPK Gunung Mulia, 1974.

Yewangoe, A. A. Mengupayakan Misi Gereja yang Kontekstual. Jakarta: Persetia, 1995. 